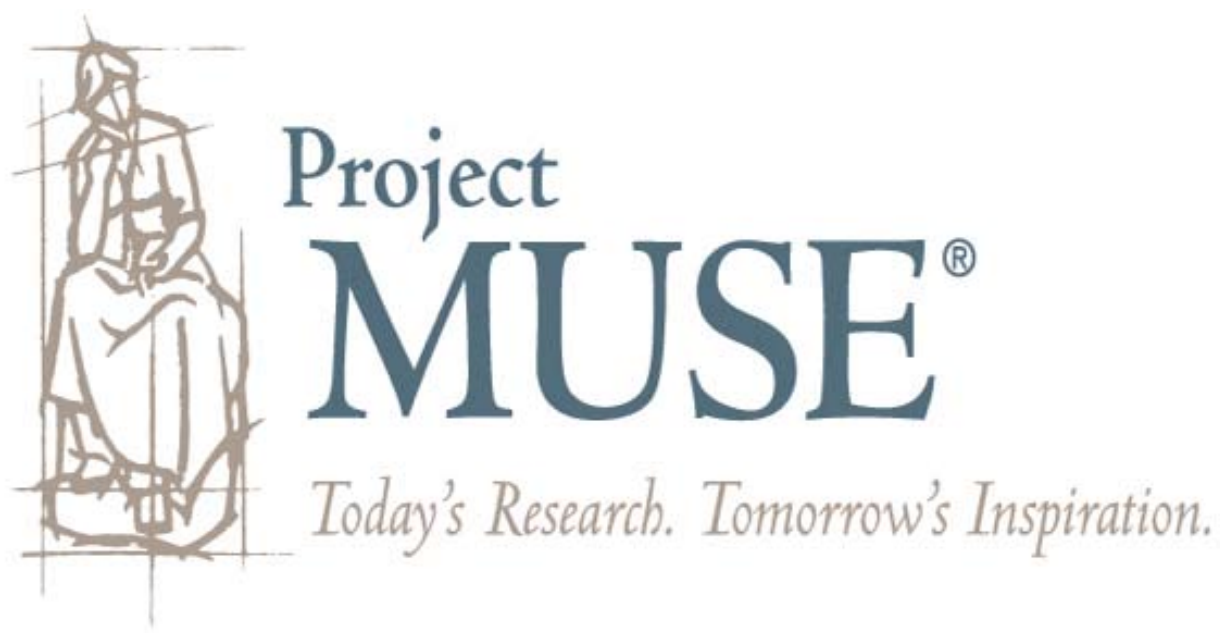




\title{
Health in Pre-Angkorian Cambodia: A Bioarchaeological Analysis of the Skeletal Remains from Phum Snay
}

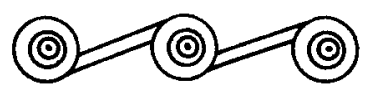

\author{
K. M. DOMETT AND D. J. W. O’REILLY
}

\section{INTRODUCTION}

Phum Snay is a village located along National Route 6 in Preah Neat Prey District, Banteay Meanchey Province, Northwest Cambodia (Fig. 1). During 2000 roadwork was undertaken to link the village with National Route 6 , construction of which revealed the presence of a number of prehistoric inhumation burials and associated artifacts. These discoveries led to the wholesale looting of the site by local villagers, and little archaeological evidence remains. Scientific excavations began at Phum Snay in 2001 and continued until 2003, led by Dr. Dougald O'Reilly, Mr. Pheng Sitha, and Mr. Thuy Chanthourn. The Banteay Meanchey Archaeological Project (BMAP) included staff and students from the Royal University of Fine Arts, Phnom Penh, the University of Otago, New Zealand, and James Cook University, Australia. The project sought to provide a data set that would shed light on the sociopolitical organization of a settlement in Northwest Cambodia during the Iron Age (c. 500 B.C.-A.D. 500) and provide evidence that could be compared to sites in Northeast Thailand in the lead up to the establishment of the state of Angkor, an important polity over parts of Southeast Asia from A.D. 800-1400 (Higham 2002). Considerable research has been undertaken on Iron Age sites in Thailand, many of which are surrounded by ramparts and ditches and have significant mortuary populations that tend to suggest a hierarchical organization of the society during the Iron Age.

Archaeological reports of the 2001 and 2003 excavations have been published elsewhere (O'Reilly and Pheng 2001; O'Reilly et al. 2004, 2006, 2008). The 2001 excavation rendered dates of 348-307 B.C. at $2 \sigma$ and the 2003 excavation results indicated dates of A.D. 75-209 at $2 \sigma$ (O'Reilly et al., 2006). These dates (c. 350 B.C.-A.D. 200) coincide with the late Iron Age or pre-Angkorian period. Based upon the nature of the artifacts and placement of the graves, it is safe to

K. M. Domett is a Senior Lecturer in the Discipline of Anatomy, School of Medicine \& Dentistry, James Cook University, Australia; D. J. W. O'Reilly is a Lecturer in the Department of Archaeology, University of Sydney, Australia. 


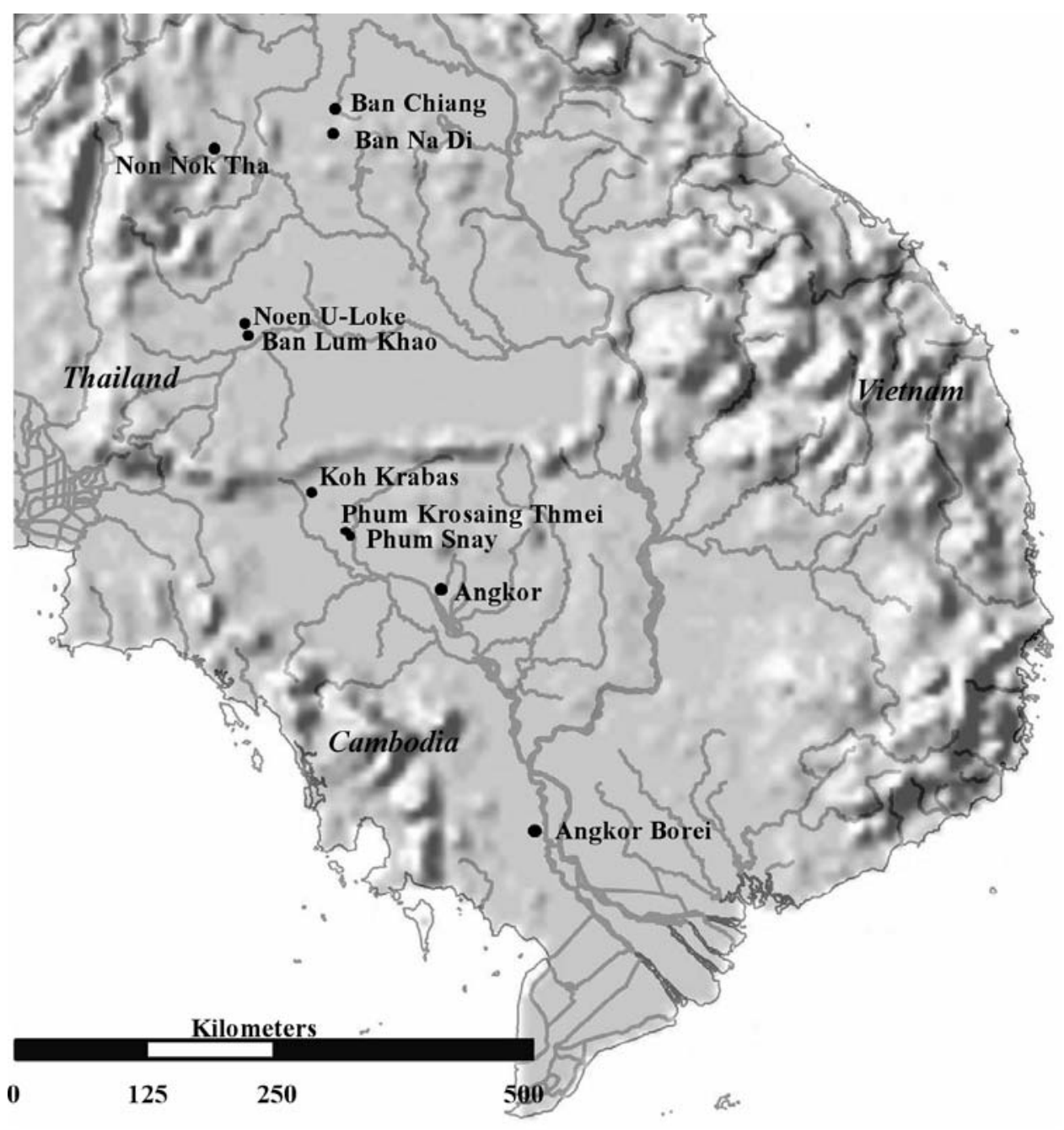

Fig. 1. Map of Southeast Asia indicating the sites mentioned in the text.

conclude that the two main excavated areas, despite being separated by c. $350 \mathrm{~m}$, share some similarities with regard to the material culture.

Twenty-three burials were scattered across the two excavations (Fig. $2 a$ and $b$ ) with no particular pattern of clustering. The orientation of the burials was usually in a east-west direction (Fig. 2) (O'Reilly et al. 2006). Mortuary ritual associated with the interments included ceramics including some black wares ("Phimai black") and grave beds lined with rice, both bearing a striking similarity to mortuary ritual in northeast Thailand at the same time period (O'Reilly et al. 2006). In contrast to the mortuary assemblages in Thailand, Phum Snay's graves contained more weapons. Some of these, such as the caches of three types of iron projectile points, may have been for hunting or warfare, others, such as the long $(>1 \mathrm{~m})$ iron swords, were more obviously of a military nature (O'Reilly et al. 2006) and 


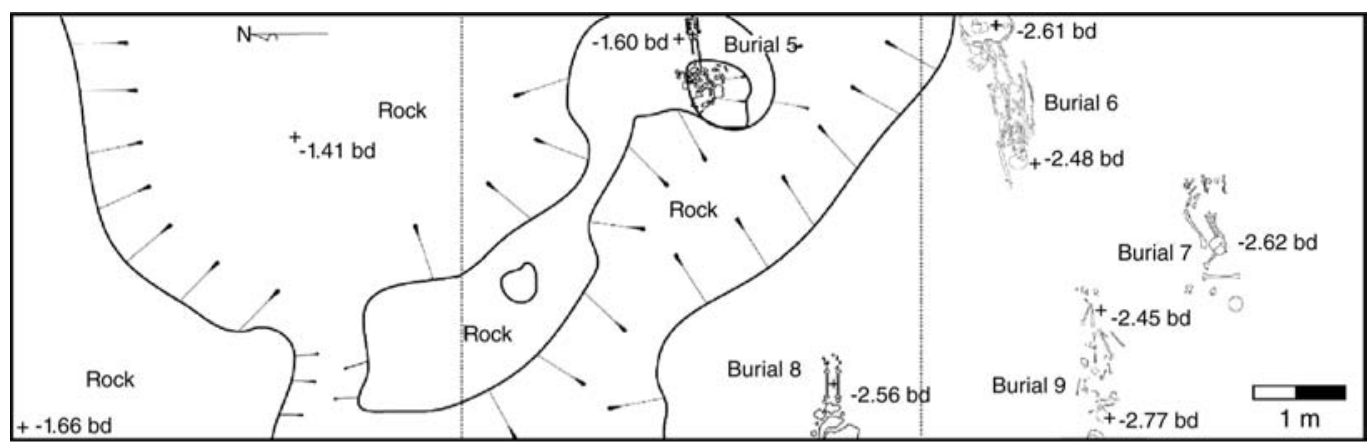

A

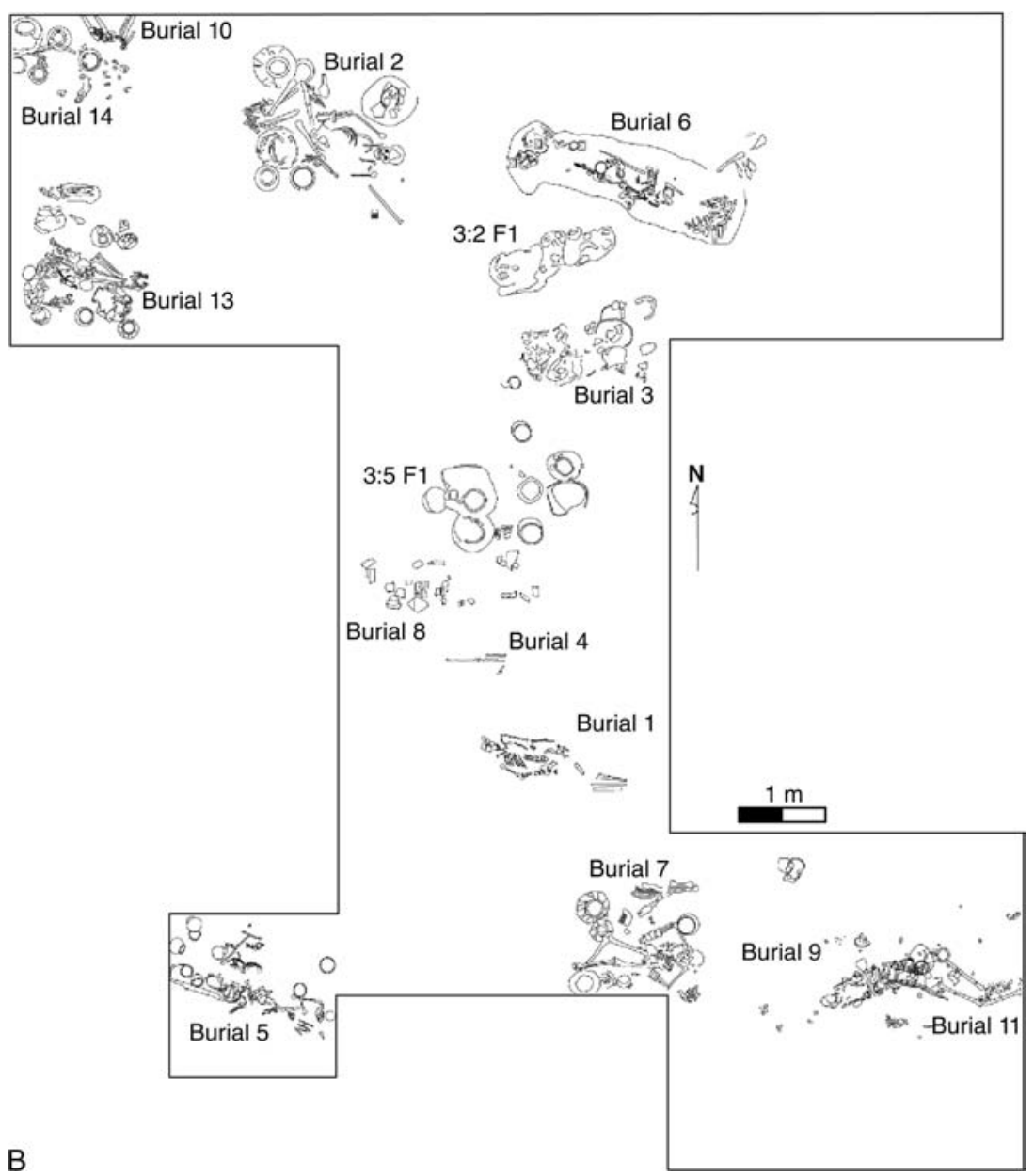

Fig. 2. Burial layout in the 2001 (A) and 2003 (B) excavations at Phum Snay (O'Reilly et al. 2006). 


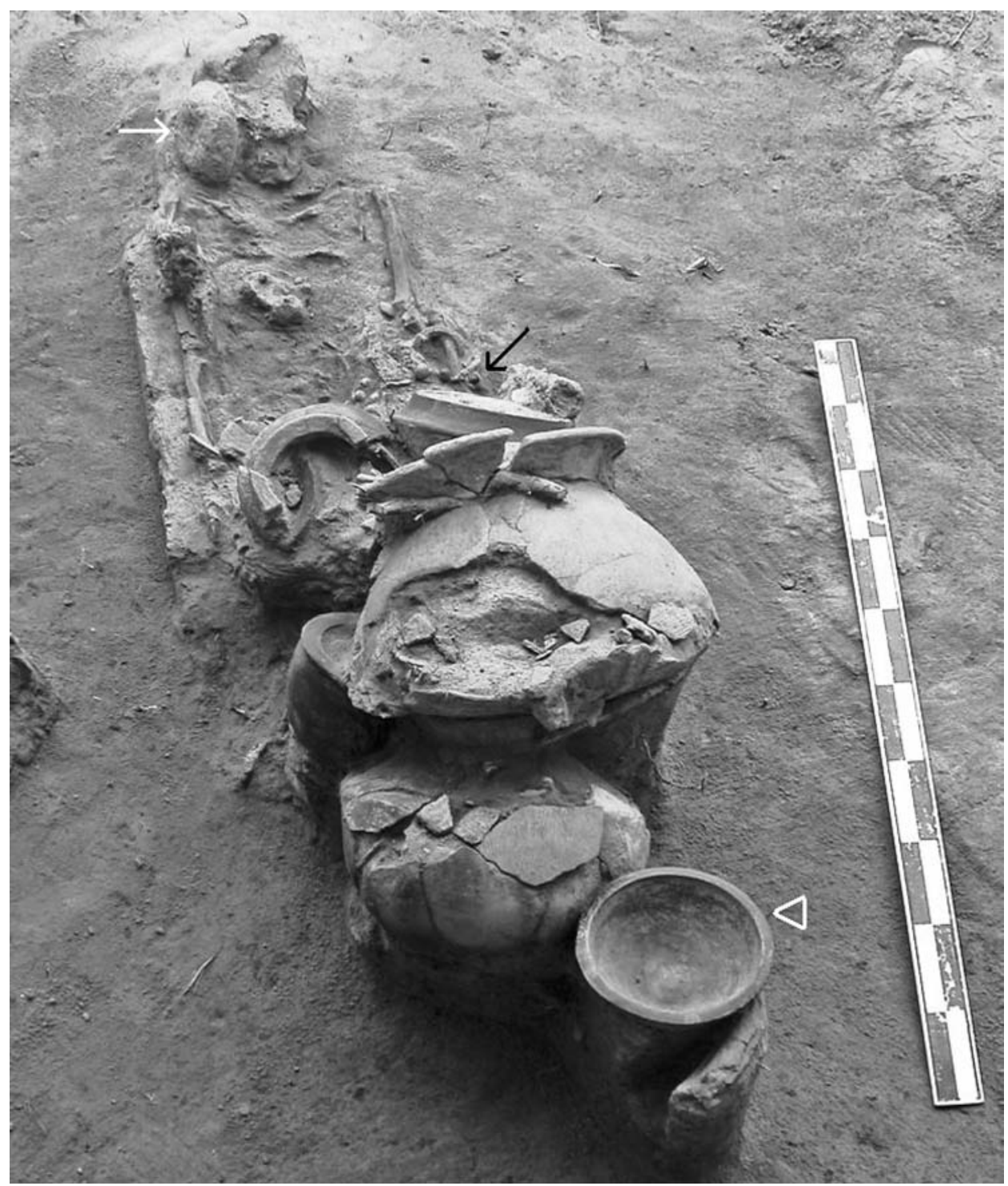

Fig. 3. Burial 9-'03. An adult female buried with an abundance of carnelian beads at her waist and wrist (black arrow), a small bronze bowl (white arrow) at the skull and a number of large pots including one of Phimai black style (white arrowhead).

were only found interred with males. The proximity of Phum Snay to the later Angkorian capital near Siem Reap may be of significance. Were the people of Phum Snay vulnerable to the changes associated with the development of the state? Alternatively, was the development of state rule a response to increasing unrest such as that between Phum Snay and other unknown groups?

If status can be inferred from grave goods then a number of individuals from Phum Snay stand out. An adult female burial (PS 9-'03) (Fig. 3) was noteworthy 


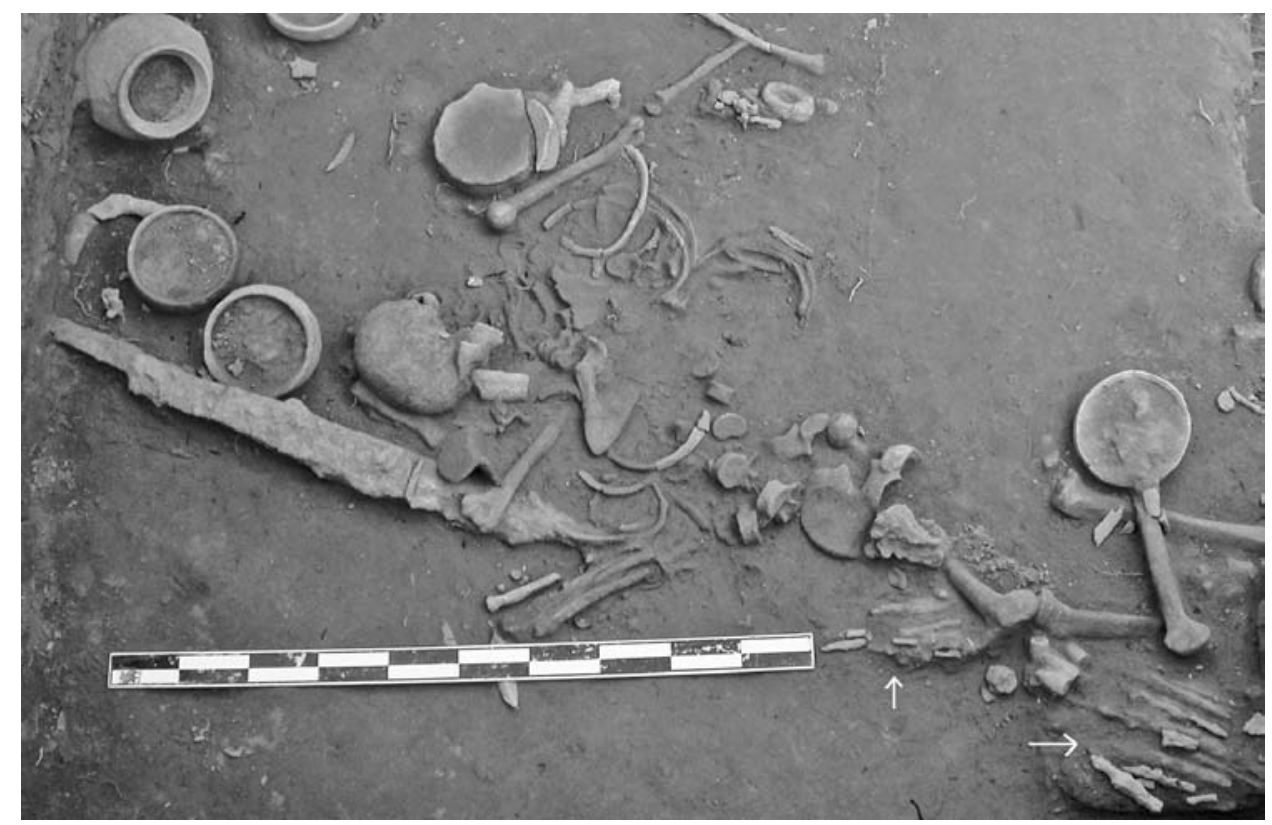

Fig. 4. Burial 5-'03 from Phum Snay. A young adult male skeleton (with some postdepositional disturbance) buried with a long iron sword (left-hand side of picture) and caches of iron projectile points (white arrows).

in the presence of over 40 carnelian beads, particularly at the waist; this woman also had a unique bronze bowl at the side of her head and was the only burial to contain a Phimai black ceramic bowl (only sherds were found elsewhere) and a gold bead. Another adult female (PS 7-'03) stood out because she was the only female to be found with a cache of iron projectile points; others were confined to male burials. A number of artifacts were sex-specific, such as spindle whorls and iron neck torques with females, and bronze bells, bone bangles, long iron swords with males (Fig. 4). While the sample size is small this type of division in grave goods adds to the evidence that this may have been a hierarchical society with gender divisions.

The major objective for this present study is to gain insights into community health and disease experienced by the prehistoric people of pre-Angkorian Phum Snay, particularly in comparison with their neighbors in Northeast Thailand. The sample size for Phum Snay is small but it was felt important to disseminate this information as the significance of prehistoric Phum Snay is considerable given that this site is one of the first Iron Age cemeteries to be excavated in this area and is propinquent in time and place to the state of Angkor (O'Reilly and Pheng 2001). The pre-Angkorian period was an important period of transition that saw advances in technological sophistication and increases in social complexity. These types of changes can dramatically influence a community's health status as bioarcheaological studies from within Southeast Asia (Domett and Tayles 2006a, b; Douglas 2006; Oxenham et al. 2005; Pietrusewsky and Douglas 2002b; Tayles 
1999; Tayles and Buckley 2004; Tayles et al., 2000) and around the world have shown (Larsen 1997).

In order for societies to develop, particularly into such large state-like societies as evident during the Angkorian civilization, it could be hypothesized that the population must have maintained a certain level of good health, although this may be variable throughout the community as social structure becomes more complex. For instance, the development and intensification of agriculture, knowledge of metal working and tools to make subsistence activities more efficient, are all related to the cultural development of a community, and can improve the general quality of life (Domett 2001). This may be seen in the skeletal record as a decrease in osteoarthritic disease or accidental injury, for example. As food sources become more reliable, an improvement may be seen in the ability of people to overcome infectious disease that would otherwise be exacerbated by poor diet (Larsen 1997; Scrimshaw 1981). In the skeletal record there would be less evidence for malnutrition or less specific nutritional deficiencies as well as fewer infectious diseases and an older average age at death.

However, increasing social complexity can lead to the establishment of hierarchical groups within a community, which can create a situation of restricted access to resources among some subgroups. For example, a subset of the community may show a decline in health related to a poorer quality (or poorer quantity) diet and more evidence of physical injury or osteoarthritis as they are expected to work harder for the community. It is also possible that a reliance on a single source of carbohydrate with the development of agriculture, such as rice in Southeast Asia, can actually decrease the nutritional quality of the diet leading to dietary deficiencies and a lowered immune response to disease. In addition, this period of time saw increasing trade and influence from foreign cultures such as India and China (Higham 2002). This may be reflected in the skeletal record with the introduction of new diseases or an increase in injury with a violent aetiology as community interactions and competition for resources increased with enlarging population sizes.

The information gained from the human skeletal remains from Phum Snay will be placed in their regional context by focusing comparisons with appropriate skeletal samples from Southeast Asia. There is little published data available on skeletal remains from sites contemporaneous and located near to Phum Snay. Recent excavations at Phum Krosaing Thmei (48 B.C.-A.D. 226) (Sok pers. comm., cited in O'Reilly et al. 2006), only $1 \mathrm{~km}$ from Phum Snay, uncovered eight skeletons (Domett 2005). The site of Prei Khmeng (A.D. 100), a temple site near the Western Baray near the Angkor temple complex some $80 \mathrm{~km}$ from Phum Snay, exposed seven burials (Chhem et al. 2004). Excavations in the south of Cambodia at the Vat Komnou cemetery at Angkor Borei (200 B.C.-A.D. 400) uncovered 61 skeletons (Pietrusewsky et al. 2006). These sites are all broadly contemporaneous with Phum Snay, however the first two are of little use at this stage as the preservation of the skeletal remains was extremely poor and the sample sizes small. There are also some collections of unprovenanced skeletal material in northwest Cambodia that have arisen through looting of prehistoric cemeteries. There is a large collection of stratigraphically unprovenanced material (MNI c. 94) from around the village of Phum Snay (which will be reported on at a later date) and a 
Table i. Dates and Sample Sizes of the Sites Referred to in this Study

\begin{tabular}{|c|c|c|c|c|c|}
\hline SITE & DATES & PERIOD & REGION & SAMPLE SIZE & $\begin{array}{c}\text { MAIN } \\
\text { REFERENCE }\end{array}$ \\
\hline Phum Snay & $\begin{array}{r}350 \text { B.C. }- \\
\text { A.D. } 200\end{array}$ & $\begin{array}{l}\text { Late Iron } \\
\text { Age or } \\
\text { Pre- } \\
\text { Angkor }\end{array}$ & $\begin{array}{l}\text { Northwest } \\
\text { Cambodia }\end{array}$ & 23 individuals & This study \\
\hline $\begin{array}{c}\text { Vat Komnou } \\
\text { (Angkor } \\
\text { Borei) }\end{array}$ & $\begin{array}{r}200 \text { B.C. }- \\
\text { A.D. } 400\end{array}$ & $\begin{array}{l}\text { Late Iron } \\
\text { Age }\end{array}$ & $\begin{array}{l}\text { Southern } \\
\text { Cambodia }\end{array}$ & 61 individuals & $\begin{array}{r}\text { (Pietrusewsky } \\
\text { et al. 2006) }\end{array}$ \\
\hline $\begin{array}{l}\text { Ban Lum } \\
\text { Khao }\end{array}$ & $\begin{array}{l}1000- \\
500 \text { в.С. }\end{array}$ & Bronze Age & $\begin{array}{c}\text { Mun River } \\
\text { valley NE } \\
\text { Thailand }\end{array}$ & 110 individuals & $\begin{array}{l}\text { (Domett 2001, } \\
\text { 2004) }\end{array}$ \\
\hline $\begin{array}{l}\text { Noen U- } \\
\text { Loke }\end{array}$ & $\begin{array}{l}300-200 \\
\text { B.C.-A.D. } \\
\text { 300-400 }\end{array}$ & Iron Age & $\begin{array}{c}\text { Mun River } \\
\text { valley NE } \\
\text { Thailand }\end{array}$ & 120 individuals & $\begin{array}{l}\text { (Tayles et al. } \\
\text { 2007) }\end{array}$ \\
\hline Ban Na Di & $600-400$ в.с. & $\begin{array}{c}\text { Late Bronze } \\
\text { to early } \\
\text { Iron Age }\end{array}$ & $\begin{array}{l}\text { Middle Chi } \\
\text { River } \\
\text { valley, NE } \\
\text { Thailand }\end{array}$ & 78 individuals & (Domett 2001) \\
\hline Ban Chiang & $\begin{array}{l}\text { c. } 2100 \text { B.C. }- \\
\text { A.D. } 200\end{array}$ & $\begin{array}{c}\text { Neolithic to } \\
\text { Iron Age }\end{array}$ & $\begin{array}{l}\text { Northern } \\
\text { NE } \\
\text { Thailand }\end{array}$ & 140 individuals & $\begin{array}{l}\text { (Pietrusewsky } \\
\text { and Douglas } \\
2002 a \text { ) }\end{array}$ \\
\hline $\begin{array}{l}\text { Non Nok } \\
\text { Tha }\end{array}$ & $\begin{array}{l}3000-2500 \\
\text { B.C. -A.D. } \\
200\end{array}$ & $\begin{array}{l}\text { Neolithic to } \\
\text { early Iron } \\
\text { Age }\end{array}$ & $\begin{array}{l}\text { Upper Chi } \\
\text { River } \\
\text { valley, NE } \\
\text { Thailand }\end{array}$ & 180 individuals & $\begin{array}{l}\text { (Douglas } \\
\quad 1996,2006)\end{array}$ \\
\hline
\end{tabular}

smaller collection $(\mathrm{MNI}=18)$ from Koh Krabas also in the northwest (Wallwork 2006).

The northeastern prehistoric Thai skeletal samples make a good basis for comparison with Phum Snay as they are located near to and also just predate the northeastern extension of the Angkorian civilization at Phimai (Fig. 1). The skeletal samples from Ban Lum Khao (Domett 2001), Noen U-Loke (Tayles et al. 2007), Ban Na Di (Domett 2001), Ban Chiang (Pietrusewsky and Douglas 2002a, b), and Non Nok Tha (Douglas 1996, 2006) (Fig. 1) will be used (Table 1). The last two sites have quite long time spans which make their summary data not indicative of a particular period in prehistory but more of a general indicator of health in these populations.

\section{THE SKELETAL DATA FROM PHUM SNAY}

This report details the collection of human remains identified during the archaeological excavations of 2001 and 2003. There were 23 burials identified over the course of the two excavations, however one burial contained no bone (Burial 8-'03), being identified only by grave goods, and a further adult burial was not removed from the ground as only a small part of this adult skeleton (the distal femora and proximal tibiae and fibulae) was within the boundaries of the excava- 
tion (Burial 10-'03). This latter burial is included in the census of the site but in no further analyses.

The skeletons varied greatly in their preservation and completeness. Four skeletons were very incomplete and these burials had likely been disturbed in the past. A further three burials were represented by only a few fragments or pieces of bone with very poor preservation but those bones present were in articulation. A total of six burials were partly articulated and partly disturbed but were mostly near complete in terms of bone preservation. A further four of the burials were also mostly near complete but had very poor bone preservation. One burial was articulated but only the lower half of the body could be recovered as the upper half was outside of the excavation square. There were only three burials that could be considered complete and fully articulated. In summary, from the total of 21 excavated burials only nine (43\%) were near complete with reasonable bone preservation.

The material discussed in this report is currently stored at the Royal University of Fine Arts in Phnom Penh.

\section{DEMOGRAPHY}

The age and sex distribution of the 22 burials is presented in Table 2. Estimation of the age at death of subadults (0-14.9 years) was based on the eruption of the dentition following Ubelaker (1989) in the first instance, followed by the comparison of diaphyseal long bone lengths with prehistoric Thai subadults if no dentition was preserved. Only two subadults (9.1\%) were identified during excavations, one a complete young child of approximately two years of age (Burial 5-'01) and the very fragmented and poorly preserved remains of a possible older adolescent (Burial 12-'03).

A multifactorial approach was taken in the estimation of the age at death of adults, although the variable condition of the skeletal material has influenced the degree of accuracy obtainable. Standard measures used included observations of late fusing epiphyses, pubic symphysis morphology, and dental wear (Buikstra and Ubelaker 1994). Adults were classified in relative age groups of young, middleaged, and old; the preservation did not generally allow any more precise estimates.

The estimation of sex for adults was based on standard morphological observations of the pelvis and cranium (Buikstra and Ubelaker 1994) and, in one case only (Burial 14-'03), by section point analysis of metric observations (based on Phum Snay individuals sexed from pelves and crania).

Adults comprised 90.9 percent of the sample (Table 2). Only young to middleaged adults were identified although 40 percent (eight individuals) of adults did not have sufficient evidence for age at death to be estimated. Of those adults with age estimates there were slightly more middle-aged adults $(7 / 12,58 \%)$ than young adults $(5 / 12,42 \%)$. Overall, a far larger proportion of the total adult sample was female $(10 / 20,50 \%)$ compared with male $(5 / 20,25 \%)$, however 25 percent $(5 / 20)$ of the adult skeletal material did not permit sex estimates.

The demographic distribution indicates that this sample is probably not a good representation of the living community from which the burials came, for two reasons. Firstly, there were only two subadults identified, comprising 9.1 percent of 
Table 2. Age and sex distribution of the excavated skeletons from Phum Snay

\begin{tabular}{|c|c|c|c|c|}
\hline AGE & MALE & FEMALE & UNKNOWN SEX & TOTAL \\
\hline $\begin{array}{l}0-5 y \\
5-10 y\end{array}$ & & & 1 & 1 \\
\hline $10-15$ y & & & 1 & 1 \\
\hline Subadults total & & & 2 & $2(9.1 \%)$ \\
\hline Young adult & 2 & 3 & & 5 \\
\hline $\begin{array}{l}\text { Middle-aged adult } \\
\text { Old adults }\end{array}$ & 3 & 4 & & 7 \\
\hline $\begin{array}{l}\text { Unknown adult age } \\
\text { Adults total }\end{array}$ & $5(25 \%)$ & $\begin{array}{l}3 \\
10(50 \%)\end{array}$ & $\begin{array}{l}5 \\
5(25 \%)\end{array}$ & $\begin{array}{l}8 \\
20(90.9 \%\end{array}$ \\
\hline TOTAL & $5(23 \%)$ & $10(45 \%)$ & $7(32 \%)$ & 22 \\
\hline
\end{tabular}

the total sample. It would normally be expected that at least 30 percent of the sample would be subadult in a prehistoric sample (Waldron 1994) and a high proportion of the subadult group would be infants, those less than one year of age. In comparative samples from a similar time period at Angkor Borei, 33 percent (20/61) were subadults (Pietrusewsky et al. 2006) and in Northeast Thailand subadults comprised 44 percent (53/120) at Noen U-Loke (Domett and Tayles 2006a), 15.7 percent (13/83) in the late Non Nok Tha group (Douglas 1996), and 36 percent $(5 / 14)$ in the late period at Ban Chiang (Pietrusewsky and Douglas 2002a).

It is difficult to make any convincing conclusions from these comparative demographic results as the Phum Snay excavated sample is so small, other than that the comparisons support the reality that the Phum Snay skeletal population is probably not representative of the living community that it came from. Subadults may have predominantly been buried elsewhere within the site or infants may have been cremated. There is little evidence of these explanations in other parts of Southeast Asia where infants, although sometimes buried in large jars, are predominantly treated in a similar manner and in the same location, as adults. Recent analysis of the distribution of infants at the Khok Phanom Di Neolithic cemetery in coastal southwest Thailand revealed that preterm infants may have in fact been buried elsewhere but all other ages are distributed amongst the adults as with many other sites (Halcrow et al. 2008). A brief mention is also made of differential burial treatment of some infant skeletons at the Non Nok Tha cemetery but there is no further elaboration (Douglas 1996). It is also possible given the more fragile nature of infant and child bones that they have simply not been preserved.

Secondly, the male to female ratio is skewed $1: 2$, where it would normally be expected to be closer to $1: 1$ (Waldron 1994). This outcome is most likely a reflection of the small sample size and the lack of age at death and sex estimates for a number of adults, rather than any bias in burial rituals. However, in order to gain a $1: 1$ ratio, the entire sample of unsexed adults would have to be male. No other site from prehistoric Thailand has shown such a disparity between the sexes (Domett 2001; Domett and Tayles 2006a; Douglas1996; Pietrusewsky and Douglas 2002a). The sex ratio from Angkor Borei was the reverse of Phum Snay with males outnumbering females $2: 1$, but no suggestion as to why this is the case at 
Table 3. Average long bone measurements (Right and left Sides Combined in CM) and stature estimates (CM) of the excavated adults from Phum Snay

\begin{tabular}{|c|c|c|c|c|c|c|c|c|c|c|}
\hline & \multicolumn{5}{|c|}{ FEMALES } & \multicolumn{5}{|c|}{ MALES } \\
\hline & $\mathrm{N}$ & MEAN & MIN & MAX & S.D. & $\mathrm{N}$ & MEAN & MIN & MAX & S.D. \\
\hline Clavicle & 5 & 13.6 & 11.9 & 15.2 & 1.3 & 5 & 14.0 & 11.7 & 15.9 & 1.8 \\
\hline Humerus & 4 & 31.9 & 30.0 & 33.9 & 2.0 & 7 & 30.8 & 27.7 & 33.6 & 2.6 \\
\hline Radius & 2 & 23.5 & 22.9 & 24.1 & 0.8 & 4 & 25.0 & 23.7 & 27.6 & 1.8 \\
\hline Ulna & & & & & & 4 & 26.0 & 25.7 & 26.4 & 0.4 \\
\hline Femur & 3 & 45.9 & 44.7 & 48.2 & 2.0 & 5 & 44.6 & 42.0 & 48.1 & 3.2 \\
\hline Tibia & 4 & 37.1 & 34.5 & 41.2 & 3.1 & 6 & 37.8 & 35.7 & 41.5 & 2.8 \\
\hline Fibula & & & & & & 3 & 35.6 & 35.1 & 35.8 & 0.4 \\
\hline Stature & 6 & 161.1 & 153.7 & 173.7 & 8.0 & 4 & 167.7 & 160.6 & 176.9 & 7.9 \\
\hline
\end{tabular}

Angkor Borei is provided (Pietrusewsky et al. 2006). Further discussion of this disparity at Phum Snay is made in the conclusions.

\section{LONG BONE LENGTH, STATURE, AND GROWTH DISTURBANCES}

Long bone lengths were measured, when possible, in situ before being removed from the ground. If the bone was excavated intact or could be easily reconstructed it was measured again after lifting using an osteometric board and this was taken as the more accurate measurement. Stature was estimated using regression equations developed on Thai and Chinese cadavers using the bone available with the least standard error (Sangvichien et al. 1985, n.d.). These equations were chosen as they make comparisons with other Southeast Asian samples straightforward and the equations generally produce the smallest variation in stature estimates for different long bone lengths. This would indicate that the prehistoric Cambodian people have similar limb proportions to the sample on which the modern Thai/Chinese equations were based, although not necessarily exactly the same.

Ten of the 20 excavated adult burials had one or more long bones measured and the average results along with stature estimates are provided in Table 3.

Phum Snay males $(n=4)$ had an average stature of $167.7 \mathrm{~cm}$, within the upper range of averages for the comparative samples $(164.7-169.3 \mathrm{~cm}$ ) (Table 4). No statistical differences were calculated between the male means from these samples (ANOVA F $=1.87$, p-value $=0.0927$ ) although this should be considered with the caveat that sample sizes are very small from Phum Snay. The tallest male at Phum Snay was Burial 6-'03 at $176.9 \mathrm{~cm}$, over $5 \mathrm{~cm}$ taller than the next tallest male at Phum Snay and over $16 \mathrm{~cm}$ than the other two males. Burial 6-'03 was an interesting burial with a long iron sword and large bovid bones at his head and feet as well as the grave having a possible resin and rice lining not seen in any other burial (O'Reilly et al. 2006). However, this was not the only burial to have such grave goods: Burial 5-'03, the shortest male $(160.6 \mathrm{~cm})$ (Fig. 4), and Burial 6-'01, the second shortest male $(161.6 \mathrm{~cm})$ were also buried with long iron swords and other weaponry for fighting or hunting. 
Table 4. Comparison of Phum Snay stature (Cm) and Linear Enamel Hypoplasia (LEH) With other prehistoric Southeast Asian populations

\begin{tabular}{|c|c|c|c|c|c|}
\hline & $\mathrm{N}$ & MEAN & RANGE & S.D. & $\begin{array}{c}\text { LEH } \\
\text { (ADULTS) }\end{array}$ \\
\hline \multicolumn{6}{|l|}{ Female } \\
\hline Non Nok Tha ${ }^{1}$ & 32 & 153.4 & $146-162$ & 4.0 & 4.2 \\
\hline Ban Chiang $^{2}$ & 24 & 154.4 & $149.2-161.0$ & 3.0 & 6.5 \\
\hline Noen U-Loke ${ }^{3}$ & 4 & 154.6 & $151.5-161.6$ & 4.7 & 15.1 \\
\hline Ban Lum Khao ${ }^{4}$ & 25 & 154.7 & $147.9-162.2$ & 3.8 & 12.4 \\
\hline $\mathrm{Ban} \mathrm{Na} \mathrm{Di}^{5}$ & 13 & 155.9 & $150.0-164.4$ & 4.0 & 12.6 \\
\hline Vat Komnou $^{6}$ & 6 & 156.6 & $151.1-159.8$ & 3.2 & $4.9^{*}$ \\
\hline Phum Snay & 6 & 161.1 & $153.7-173.7$ & 8.0 & 0 \\
\hline \multicolumn{6}{|l|}{ Males } \\
\hline Ban Lum $\mathrm{Khao}^{4}$ & 18 & 164.7 & $152.4-174.9$ & 6.2 & 11.2 \\
\hline Non Nok Tha ${ }^{1}$ & 32 & 165.4 & $158-173$ & 3.5 & 5.3 \\
\hline Ban Chiang $^{2}$ & 29 & 165.7 & $160.3-173.7$ & 3.6 & 7.6 \\
\hline Vat Komnou ${ }^{6}$ & 6 & 167.0 & $160.5-174.2$ & 5.9 & $12.9^{*}$ \\
\hline Phum Snay & 4 & 167.7 & $160.6-176.9$ & 7.9 & 7.0 \\
\hline Ban $\mathrm{Na} \mathrm{Di}{ }^{5}$ & 17 & 168.0 & $159.5-176.0$ & 4.9 & 15.7 \\
\hline Noen U-Loke ${ }^{3}$ & 9 & 169.3 & $165.3-173.3$ & 3.1 & 6.6 \\
\hline
\end{tabular}

1. Douglas (1996); 2. Pietrusewsky and Douglas (2002a); 3. Domett and Tayles (2006a), Tayles et al. (2007); 4. Domett (2004); 5. Domett (2001); 6. Pietrusewsky et al. (2006). Note: this latter study used Sjøvold (1990) regression equations.

* Canines and incisors only.

The six females with estimates averaged $161.1 \mathrm{~cm}$ in stature, ranging from $153.7 \mathrm{~cm}$ to $173.7 \mathrm{~cm}$, a wide range of $20.0 \mathrm{~cm}$. A statistically significant result was calculated amongst the female comparative sample means (Table 4) (ANOVA F $=3.52, \mathrm{p}$-value $=0.0033$ ). When individual Student t-tests were calculated between Phum Snay and each comparative sample, Phum Snay females were not statistically different than any of these other samples. However, one middle-aged female from Phum Snay (Burial 7-'03) was particularly tall at 173.7 $\mathrm{cm}$, considerably taller than any female so far identified from prehistoric mainland Southeast Asia. (Note: There is little biological doubt that Burial 7-'03 is a female as sex estimation was based on reliable pelvic morphology). The previous tallest woman was recorded from Ban Kao in central Thailand at $166.7 \mathrm{~cm}$ (Tayles 1999). Even if Burial 7-'03 is statistically considered an outlier, the remaining female average is $158.5 \mathrm{~cm}$, still the highest of the average range (153.4$156.6 \mathrm{~cm}$ ) amongst the comparative samples (Domett 2001, 2004; Domett and Tayles 2006a; Douglas 1996; Pietrusewsky and Douglas 2002a; Pietrusewsky et al. 2006; Tayles et al. 2007) (Table 4).

Archaeologically the grave of this very tall woman was quite interesting: on one hand she was the only woman to be buried with a cache of iron projectile points (others were found only with males) but her grave goods did include spindle whorls that were only found with females. The burial of this woman also had some unique grave goods including bronze finger rings with buffalo horns, a motif that is reflected in pottery "epaulettes" with iron or bronze bull horns attached, artifacts found with the stratigraphically unprovenanced skeletal remains and in an adult female burial (PS 13-'03) (O'Reilly et al. 2008). This woman was 
also only one of two individuals to be buried with a large iron torque around their neck (the other was a female, Burial 13-'03) and a glass earring (the other was a male, Burial 6-'01).

It is possible that this woman was an immigrant to the community, and isotope studies, particularly strontium analysis, are under way. This type of study was recently carried out on the Ban Chiang skeletal material and indicated the presence of some "non-local" isotope signatures, mostly men but also one woman distinguished by a different burial type (Bentley et al. 2005). The question of whether this non-local isotope signature indicates immigrants or locals consuming non-local food is still unanswered (Bentley et al. 2005). Strontium isotope studies from Khok Phanom Di indicate a relationship between tall stature and high strontium ratios, higher compared to other females in the early phases of the site suggesting that these women were immigrants (Bentley et al. 2007). Planned strontium studies on the Phum Snay skeletal remains should yield more information about the movement of people as well as marital residence during this important time period.

It is interesting to note that the average stature for men and women at Phum Snay is most similar to the other Cambodian sample of Vat Komnou (Pietrusewsky et al. 2006) (Table 4). However, this study used the Sjøvold (1990) regression equations to estimate stature, which when applied to the Phum Snay data, create radically different results including estimating the stature of Burial 7-'03 at $182.9 \mathrm{~cm}$ that seem somewhat unrealistic. The individual long bone length data has not been published from Vat Komnou so recalculation of the statures based on the Thai-Chinese formula has not been possible.

Linear enamel hypoplasia (LEH), as evidenced by a horizontal groove across the enamel of a tooth, indicates a period of growth disruption during the formation of the tooth (i.e., during infancy and early childhood). LEH was observed in only 7 percent $(7 / 100)$ of male teeth $(3 / 5$ individuals $)$ and 0 percent $(0 / 68)$ in female teeth $(0 / 5$ individuals) from Phum Snay (Table 4$)$. In comparison with Southeast Asian samples, the absence of LEH in females is problematic with other samples ranging from 4.2 percent at Non Nok Tha to 15.1 percent at Noen ULoke (Table 4), but is probably a reflection of the small sample size. The percentage of male teeth with LEH at Phum Snay is on par with that from Noen U-Loke and Ban Chiang with other sites having much higher values $(>10 \%)$. There does not seem to be any consistent pattern of males more commonly affected than females amongst the samples.

There appears to be no correlation between stature and LEH at Phum Snay in the limited sample of four males with both a stature estimate and dentition. Burial 6-'03, a middle-aged adult, was one male with evidence of LEH but was also the tallest of the four males measured indicating that whatever had caused his growth disruption as a boy had not affected his final attained stature-it would appear he was able to compensate for the growth disruption with a period of catch-up growth that can occur if nutrition was adequate post-disruption (HussAshmore et al. 1982). Another male (Burial 5-'03) with evidence of LEH was the shortest male recorded perhaps indicating that his growth disruption was more severe or prolonged enough to result in a reduction in final stature or that no suitable period of catch-up growth could occur due to an insufficient diet (HussAshmore et al. 1982). This adult male died as a young adult, which could further 
augment the case that this man was somewhat frail and succumbed to disease; alternatively, he may have died as the result of an accident. The other short male (Burial 6-'01) had no evidence of LEH but also died as a young adult. The third male (Burial 1-'01) with LEH could not be assessed for stature and was thought to have survived through to at least middle age. The remaining male with no evidence of LEH was the second tallest (Burial 2-'03) and died in middle age. It is difficult to draw conclusions from this evidence but it is possible that inequalities in access to resources or care when sick existed between individuals or, alternatively, the small sample is not genetically homogenous and males had different genetic potentials for stature.

\section{HEALTH}

\section{Dental Health}

Only a very small dental sample was recovered from this material: a total of 195 complete, erupted teeth and 279 tooth positions among six females, five males, and one adolescent. This equates to an average of 23.3 tooth positions identified per individual from a possible 32 . Table 5 presents the evidence for the adult sample for advanced attrition (exposure of the pulp cavity), caries, periapical cavities (abscesses), and antemortem tooth loss (AMTL).

Very low rates of advanced attrition were recorded in the female sample $3.8 \%$ for females, 9.3\% for males) in comparison with other Southeast Asian prehistoric samples (Table 6). The prevalence of advanced tooth wear in the comparative skeletal samples ranged from 4.6 percent in Non Nok Tha females to 22.2 percent in Noen U-Loke females. Phum Snay females were statistically lower compared to Noen U-Loke (FET p-value $=0.0001)$ and Ban Na Di (FET p-value $=$ 0.0026), the two sites with the highest levels of advanced wear. Within the male samples, which ranged from 8.1 percent at Non Nok Tha to 22.2 percent at Ban Chiang, Phum Snay was again statistically lower than the two samples with the highest levels: Ban Lum Khao $\left(\mathrm{Chi}^{2}\right.$ statistic $=5.58$, p-value $\left.=0.0181\right)$ and Ban Chiang $\left(\mathrm{Chi}^{2}\right.$ statistic $=9.41, \mathrm{p}$-value $\left.=0.0022\right)$.

In comparison, caries rates in Phum Snay females were on the higher side $(10.8 \%)$ of the comparative samples range $(1.2 \%$ to $8.5 \%)$, but were only statistically higher than Non Nok Tha females $\left(3.1 \%, \mathrm{Chi}^{2}\right.$ statistic $=11.24, \mathrm{p}$-value $=$ 0.0008). This is particularly interesting as, with the caveat of a small sample size, it

Table 5. Dental pathology in Phum Snay adults

\begin{tabular}{|c|c|c|c|c|c|c|c|}
\hline & \multicolumn{2}{|c|}{ MALE } & \multicolumn{2}{|c|}{ FEMALE } & \multicolumn{2}{|c|}{ TOTAL } & \multirow{2}{*}{$\begin{array}{c}M V S . F \\
F E T P-V A L U E\end{array}$} \\
\hline & $\mathrm{A} / \mathrm{N}$ & $\%$ & $\mathrm{~A} / \mathrm{N}$ & $\%$ & $\mathrm{~A} / \mathrm{N}$ & $\%$ & \\
\hline Advanced attrition & $10 / 108$ & 9.3 & $3 / 79$ & 3.8 & $13 / 187$ & 7.0 & 0.2436 \\
\hline Caries & $8 / 105$ & 7.6 & $9 / 83$ & 10.8 & $17 / 188$ & 9.0 & 0.6098 \\
\hline Periapical cavities & $3 / 130$ & 2.3 & $0 / 51$ & 0 & $3 / 181$ & 1.7 & 0.5600 \\
\hline Pathological AMTL & $1 / 145$ & 0.7 & $1 / 122$ & 0.8 & $2 / 267$ & 0.7 & 1.0000 \\
\hline Ablated AMTL & $24 / 145$ & 16.6 & $15 / 122$ & 12.2 & $39 / 267$ & 14.6 & 0.3859 \\
\hline
\end{tabular}


Table 6. Phum Snay dental health comparison with Southeast Asian prehistoric SAMPLES $(\%)$

\begin{tabular}{|c|c|c|c|c|}
\hline & ADVANCED ATTRITION & CARIES & PERIAPICAL CAVITIES & PATHOLOGICAL AMTI \\
\hline \multicolumn{5}{|l|}{ Females } \\
\hline Phum Snay & 2.5 & 10.8 & 0 & 0.8 \\
\hline Vat Komnou $^{1}$ & n.c.d. & 5.3 & 0.9 & 1.4 \\
\hline Ban Lum Khao ${ }^{2}$ & 6.3 & 6.7 & 1 & 5.1 \\
\hline Noen U-Loke ${ }^{3}$ & 22.9 & 3.2 & 5.8 & 6.9 \\
\hline Ban Chiang ${ }^{4}$ & 9.3 & 5.9 & 4.9 & 6.2 \\
\hline Non Nok Tha ${ }^{5}$ & 4.6 & 3.1 & 1.2 & 5.5 \\
\hline Ban $\mathrm{Na} \mathrm{Di}^{6}$ & 17.9 & 8.2 & 0.8 & 12.9 \\
\hline \multicolumn{5}{|l|}{ Males } \\
\hline Phum Snay & 8.3 & 7.7 & 2.3 & 0.7 \\
\hline Vat Komnou $^{1}$ & n.c.d. & 1.2 & 3.3 & 5.5 \\
\hline Ban Lum Khao ${ }^{2}$ & 18.8 & 1.8 & 1.7 & 5.3 \\
\hline Noen U-Loke ${ }^{3}$ & 10.4 & 4.2 & 6.1 & 2.4 \\
\hline Ban Chiang ${ }^{4}$ & 20.9 & 8.5 & 7.6 & 7.3 \\
\hline Non Nok Tha ${ }^{5}$ & 8.1 & 2.3 & 2.6 & 9.1 \\
\hline Ban $\mathrm{Na} \mathrm{Di}^{6}$ & 9.7 & 3.3 & 2.8 & 1.5 \\
\hline
\end{tabular}

1. Pietrusewsky et al. (2006); 2. Domett (2004) (note these values are slightly different than Domett (2001) as a reassessment has been carried out since this publication); 3. Tayles et al. (2007); 4. Pietrusewsky and Douglas (2002a); 5. Douglas (2006); 6. Domett (2001).

n.c.d. $=$ no comparable data.

goes against the recent hypothesis that caries rates decreased through time in prehistoric Thailand with the intensification of rice agriculture (Tayles et al. 2000). The other late Iron Age sites, Noen U-Loke and Vat Komnou, do have quite low caries rates consistent with this pattern. When the larger, stratigraphically unprovenanced material from Phum Snay is analyzed it will be interesting to see if this high rate of caries persists.

Phum Snay female caries rates were higher than those in males (7.6\%) but not to a statistical level (FET p-value $=0.6098$ ). However Phum Snay males had a much higher rate of attrition than females (although not to a statistical level, FET $\mathrm{p}$-value $=0.2436$ ) that may have removed the sites for, or evidence of, caries in some teeth. Females showed a higher caries prevalence than males in all sites except Ban Chiang (three to a statistical level: Ban Lum Khao $\mathrm{Chi}^{2}$ p-value $=$ 0.0004; Ban Na Di Chi ${ }^{2}$ p-value $=0.0171$; Vat Komnou $\mathrm{Chi}^{2}$ p-value $=0.0437$ ) (Table 6). It is common worldwide for females to have higher caries rates than males and it may indicate differences in diet stemming from sexual divisions in the tasks of food procurement (Larsen et al. 1991).

Periapical cavities were rarely seen in Phum Snay, as is the case in many of the other comparative samples ranging from $1.7 \%-7.6 \%$ in males and $0 \%-5.8 \%$ in females (Table 6). No cavities were observed in females from Phum Snay and only 2.3 percent in males. The latter was statistically lower compared to Ban Chiang males $\left(7.6 \%, \mathrm{Chi}^{2} \mathrm{p}\right.$-value $\left.=0.0291\right)$.

Pathological AMTL was very low in Phum Snay males (0.7\%) and females $(0.8 \%)$. This may be a reflection of the lack of older adults in this sample as this is a strongly age-related dental problem. Comparative samples ranged from 1.4 
percent in females from Vat Komnou up to 12.9 percent in Ban $\mathrm{Na}$ Di females but most values were around the 5\%-6\% range (Table 6). Statistically, Phum Snay male values were significantly lower than all Northeastern Thai male samples (Ban Lum Khao $\mathrm{Chi}^{2}$ p-value = 0.0349; Ban Na Di FET p-value =0.0001; Ban Chiang $\mathrm{Chi}^{2} \mathrm{p}$-value $=0.0157$; Non Nok Tha $\mathrm{Chi}^{2} \mathrm{p}$-value $=0.0250$; Noen U-Loke $\mathrm{Chi}^{2} \mathrm{p}$-value $\left.=0.0034\right)$. Phum Snay female values were statistically lower than all except Ban $\mathrm{Na}$ Di and Noen U-Loke (Ban Lum Khao Chi ${ }^{2}$ p-value $=0.0158 ;$ Ban Chiang $\mathrm{Chi}^{2}$ p-value $=0.0025 ;$ Non Nok Tha $\mathrm{Chi}^{2}$ $\mathrm{p}$-value $=0.0005 ;$ Vat Komnou FET p-value $=0.0249)$.

Overall it is apparent that while caries and advanced wear were present at Phum Snay, they had very little consequence in terms of continuing to periapical infection and/or eventual tooth loss as these conditions normally do. This could be a result of the sample not including any older adults as all these pathologies take time to accumulate. Alternatively these people may have been relatively healthy and able to fight off infection in the periapical bone (from caries or advanced attrition) and thus did not lose as many teeth prematurely.

An interesting pattern of antemortem tooth loss unrelated to pathology was observed in many individuals in Phum Snay (Fig. 5). Of nine individuals with a complete anterior maxilla or mandible, eight (89\%) had antemortem loss of some anterior dentition, predominantly in the maxilla (Table 7). This loss was restricted to the maxillary and mandibular canines and lateral incisors, and the mandibular central incisors in various patterns. The loss presented in a symmetrical pattern in the majority of individuals and adequate space remained for the missing teeth. These factors tend to rule out congenital absence and support intentional ablation. There appeared to be no association with either sex or age. The youngest individual to have ablated teeth was a young adult male, approximately 18-22 years (Burial 6-'01). An assessment of ablation in the excavated remains has previously been presented (Domett and Tayles 2004) and will be augmented with further substantial evidence for ablation in the large stratigraphically unprovenanced Phum Snay collection in a later report.

Evidence for ablation in Cambodia is not reported to be present at Vat Komnou (Pietrusewsky et al. 2006) but has been observed in some dentition from Prei Khmeng (Pottier pers. comm.), Krasang Thmey (Domett 2005), and stratigraphically unprovenanced material from Koh Krabas (Wallwork 2006). In the Iron Age in northeastern Thailand the evidence is not as strong as in Cambodia. There were a large proportion of missing anterior teeth in the Noen U-Loke material, but most cases were more likely congenital absence rather than intentional ablation because of the lack of symmetry and space (Nelsen et al. 2001). Expanding out from northeast Thailand, ablation has been recorded in the Neolithic sample of Khok Phanom Di (Tayles 1996) and there are some similarities in the patterns of loss between Phum Snay and this sample, particularly in the frequent loss of the maxillary lateral incisors. A further Neolithic Thai sample, this time from central Thailand at Ban Kao, has also provided evidence of ritual anterior tooth loss (Sangvichien et al. 1969).

Ablation appears to have a reasonably long history in Southeast Asia and worldwide where it has been documented for a wide range of prehistoric and historic populations including those of Asian and Pacific groups such as China and Japan (Han and Nakahashi 1996; Takenaka et al. 2001), Taiwan, Indonesia, and 


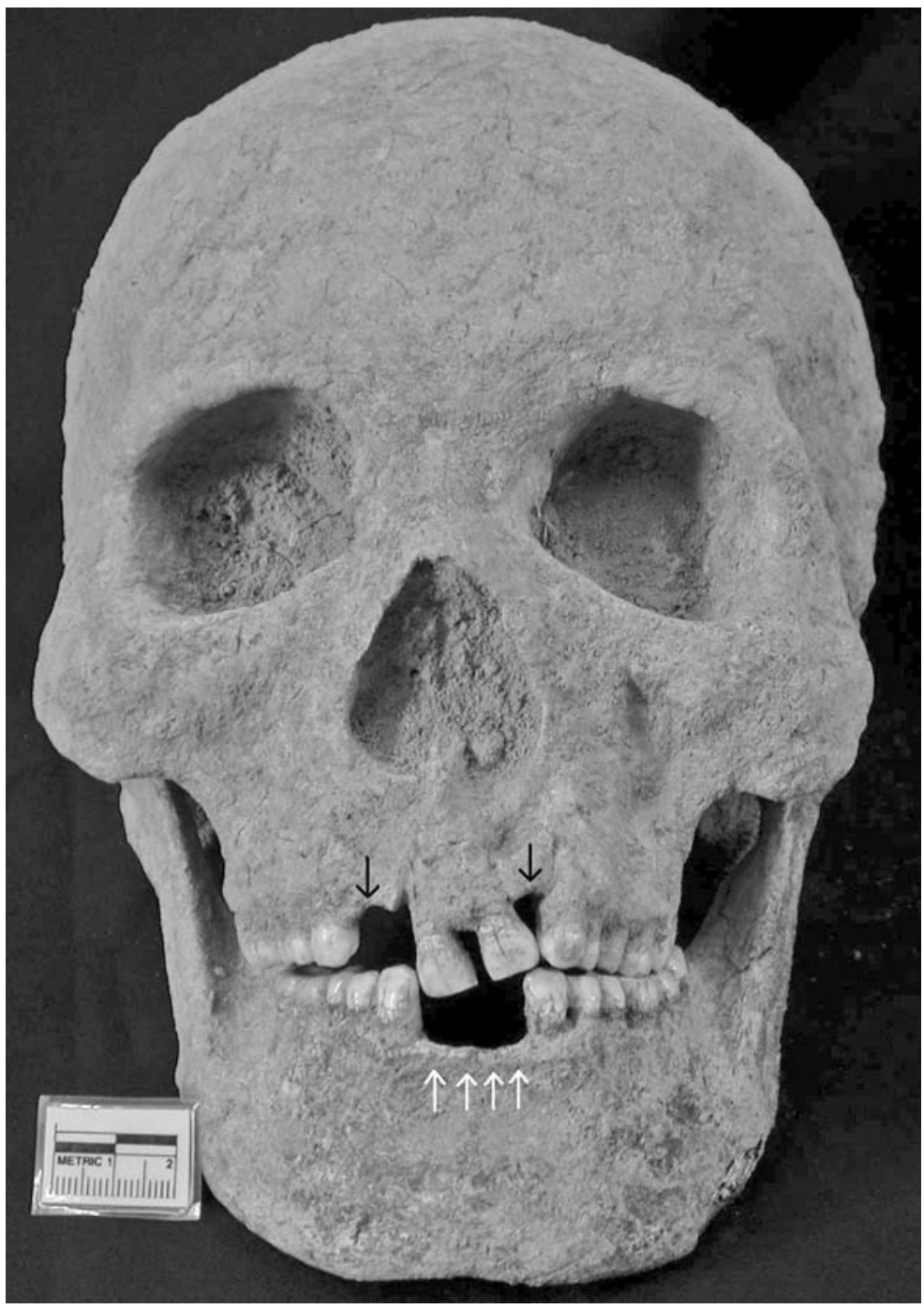

Fig. 5. Burial 6-'01 from Phum Snay, a young adult male (18-22 years old) with intentional ablation of the maxillary lateral incisors (black arrows) and all four mandibular incisors (white arrows).

Table 7. Ablation in the anterior dentition at Phum Snay

\begin{tabular}{|c|c|c|c|c|c|c|}
\hline & \multicolumn{2}{|c|}{ MALE } & \multicolumn{2}{|c|}{ FEMALE } & \multicolumn{2}{|c|}{ TOTAL } \\
\hline & $\mathrm{A} / \mathrm{N}$ & $\%$ & $\mathrm{~A} / \mathrm{N}$ & $\%$ & $\mathrm{~A} / \mathrm{N}$ & $\%$ \\
\hline Maxilla & $5 / 5$ & 100 & $3 / 3$ & 100 & $8 / 8$ & 100 \\
\hline Mandible & $3 / 4$ & 75 & $1 / 3$ & 33 & $4 / 7$ & 57 \\
\hline Individual & $5 / 5$ & 100 & $3 / 4$ & 75 & $8 / 9$ & 89 \\
\hline
\end{tabular}

A = Individuals with one or more tooth ablated; $\mathrm{N}=$ Number of observable anterior maxillae and/ or mandible. 
Australia (cited in Tayles 1996), and Hawai'i (Pietrusewsky and Douglas 1993). There are many theories concerning the meaning of dental ablation including coming-of-age, marriage, mourning, tribe or family association, ornamentation and beautification (Han and Nakahashi 1996; Tayles 1996). At present there is no evidence to help pinpoint the intent behind the ablation at Phum Snay but a forthcoming paper will investigate this more fully in this material and the stratigraphically unprovenanced material from Phum Snay.

\section{Skeletal Health}

There was very little significant pathology amongst the 21 individuals from Phum Snay. Six individuals (three males and three females) had evidence of degeneration of the spine either in the form of vertebral osteophytosis, osteoarthritis of apophyseal facet joints or, in one case, Schmorl's nodes. All three major regions of the spine-cervical, thoracic, and lumbar-were affected in these individuals, but the majority were not particularly severe cases and were unlikely to have had significant effects on their mobility, perhaps with the exception of the severe cervical degeneration (C4, C7) in Burial 1-'01, a middle-aged male. Also of significance was the accelerated spinal degeneration, including Schmorl's nodes, in Burial 6-'01, a young man of only 18-22 years.

Three individuals (one male and two females) had evidence of osteoarthritis in extraspinal joints, with no joints consistently affected among the three individuals. Amongst the three individuals all major joints-shoulder, elbow, hip, knee, and ankle-were affected with the exception of the wrist. Only one case, the right foot of Burial 14-'03, an adult female, showed particularly severe signs of degeneration.

Two individuals had evidence of healed fractures of the hand (both female) and a further two individuals (one female and one male) had possible evidence of healed fractures of their right clavicles. These fractures are all considered to be quite minor, affecting only the small diameter bones that would require less force to break and little treatment to heal.

There was only one individual, Burial 8-'01, with any visible sign of infection. This young adult female had an area of remodeled (healed) periostitis on the posterior surface of the lower midshaft of the right tibia. This was most likely a localized area of infection beneath a wound although it is unusual to find this type of pathology on the posterior aspect of the tibia as it is more protected by overlying muscle than the anterior surface of the bone.

It is not uncommon to find any of these health issues in prehistoric skeletal samples-certainly osteoarthritis is virtually ubiquitous in Southeast Asian prehistory (Domett 2001), as are minor fractures (Domett and Tayles 2006b). The evidence of injury in Phum Snay does not augment the theory that the Phum Snay community was involved in violence (O'Reilly and Pheng 2001); however the sample here is very small and observations are limited to injuries that are visible in bone. The large collection of stratigraphically unprovenanced skeletal material from Phum Snay tells a different story with a considerable amount of cranial trauma observed, mostly in the form of depression fractures (Domett and Buckley 2006). 


\section{CONCLUSIONS}

The pre-Angkorian period in northwest Cambodia was potentially a time of great social change and it is interesting to see the effects of cultural change on human health. Unfortunately the small sample of Phum Snay can only provide a hint of life during this time.

Demographically the sample is not representative of the living population as a whole with very few infants and children and no older adults identified. In addition, females outnumber males $2: 1$. If this latter pattern was evident in a larger sample it could be tempting to link this with the archaeological evidence for militarized society at Phum Snay (O'Reilly and Pheng 2001; O'Reilly et al. 2008). Weaponry and potential military paraphernalia found in graves at Phum Snay include long iron swords (some up to $1 \mathrm{~m}$ ) in three male burials, projectile points (potentially for fighting and/or hunting) in five burials (four male and one female), and ceramic "epaulettes," one with a young male, PS 5-'03), and two with a young woman, PS 13-'03, with iron bull horns. The bovine motif is continued among other artifacts with a bronze finger ring with bronze horns attached found with Burial 7-'03, the tall middle-aged woman discussed above. Unprovenanced artifacts reported by villagers during their looting included more ceramic epaulettes, iron swords and horned bronze finger rings as well "daggers" and bronze helmets (O'Reilly et al. 2008).

The lack of males in the parts of the cemetery excavated could suggest that these men were buried elsewhere, perhaps dying and being buried away from home during warring and/or hunting trips. The lack of older individuals indicates many did succumb to a premature death although the cause of death-disease, accident, or violence-is unknown. Without a larger sample such conclusions are somewhat premature. The amount of weaponry at Phum Snay is a point of difference in comparison with other Iron Age sites in Thailand (O'Reilly et al. 2006) and, as mentioned above, cranial evidence from the stratigraphically unprovenanced skeletal material adjacent to the excavations, strongly suggests interpersonal violence on some level was part of Phum Snay life (Domett and Buckley 2006). This evidence will be detailed in an upcoming study in which over 20 percent of adult crania (male and female) show healed or perimortem cranial injury. Thus skeletal and archaeological evidence for warfare at Phum Snay is providing evidence of an unsettled period that may have been one small part of the impetus for the development of the state of Angkor.

While the lack of individuals in the older age range is not an indicator of good health, other evidence indicates general health was adequate in the people of Phum Snay. This could further support the idea that people were dying prematurely by accident or violence rather than through disease as there is very little evidence of disease in the skeletal remains. Only a small amount of dental problems and a few cases of minor injury and joint degeneration were observed. Growth disturbance and infectious disease were also minimal. This may be at least partially attributable to the apparent adequate diet of the people of Phum Snay. While much evidence of diet does not survive in the archaeological record, it is assumed that rice agriculture was a way of life at Phum Snay based on the presence of rice sickles and rice in some grave fills. It is possible to conclude from 
animal bone studies that the diet of this community was quite good, at the very least it was varied in terms of protein (O'Reilly et al. 2006). Burial and nonburial animal bone include domestic species (many with butchering marks), such as water buffalo, cattle, pig, dog, chicken, duck, and wild species such as deer, serow, boar, binturong, leopard and jungle cats, tortoises and turtles, crocodile, monitor lizard, as well as bird, fish, and shellfish (O'Reilly et al. 2006).

The wild animal species also provide a potential indication of the surrounding environment or which animals would have been hunted away from the community or obtained through trade. Given the wide variety of species present the animal bones "reveal a broad-spectrum foraging economy that exploited a wide range of ecosystems: forests, grass- and marshlands, rivers, inundated fields" (O'Reilly et al. 2006:209). Most of these environments are near to the site of Phum Snay but at least one species, the serow, indicated that some hunting occurred a long way from home or that this species was obtained through trade. The favored environment of this animal, that of arid mountains with open forest, is not in the near vicinity of Phum Snay (O'Reilly et al. 2006). The presence of this exotic species may indicate that the prehistoric occupants of Phum Snay were involved in an exchange network, a possibility supported by the presence of ceramics similar to those found at contemporaneous sites in Northeast Thailand (see below).

The wide range of stature estimates in the few individuals assessed may indicate that access to these varied foodstuffs was restricted in some members of the community. If grave goods are taken as an indicator of wealth in life (certainly a contestable theory) the stature evidence suggests a structured, hierarchical society as is commonly found in Iron Age sites from nearby northeast Thailand (Higham 2002). However a wide range of statures within a group may also indicate that the group was not genetically homogenous, with a mix of locals and immigrants in the village.

There are a number of other explanations for the generally taller stature in preAngkorian Cambodian women discussed above. It is possible that the regression equations based on modern Thai and Chinese are not appropriate for this Cambodian skeletal sample (however they are the most appropriate that are available as discussed above). It is also quite likely that the small sample size is skewing the average - it cannot be changed that Burial 7-'03 was a tall woman, but if the sample size had been larger the average may have been lower and more representative. The Phum Snay sample is from the latest cultural period of the comparative sites and, with the caveat of a small sample size, their tall stature could be an indicator of either (i) improved health and nutrition, (ii) a genetically heterogenous sample, or (iii) a genetically higher potential for stature than other Southeast Asian groups so far studied. Evidence to date would suggest that option (ii) is particularly relevant for Phum Snay females with the particularly tall woman, Burial 7-'03, likely to have been an immigrant to the community, perhaps entering for marriage.

The evidence from the dentition also provides some glimpse into the dietary habits of the people of Phum Snay and may provide some indication regarding social structure. As mentioned above, male and female caries and advanced attrition rates may be linked to a sexual division of labor. It has previously been reported that in populations where men hunted they may have eaten more pro- 
tein and while women gathered food or tended crops they ate more plant material (Larsen 1997), thus creating different dental pathology profiles in men and women. These divisions of labor tasks would still have been evident in an agricultural society like Phum Snay and are reflected in the dental health results. Females were consuming foodstuffs that contained a higher cariogenic component, such as foods high in sugars and carbohydrates, although the latter are not all equally cariogenic. There is some evidence that rice is not a particularly highly cariogenic food compared to other carbohydrates such as maize or wheat (Domett and Tayles 2007; Sreebny 1983; Tayles et al. 2000). Other candidates for cariogenesis might be taro, yams, bananas, or other fruits with a high sugar content.

The possibility that the people of Phum Snay were either traveling or trading is supported by the presence of ceramics similar to Phimai black pottery and nonlocal animal bones (O'Reilly et al. 2006) (Fig. 3). The particularly characteristic Phimai black pottery has been found in many prehistoric sites in Thailand, particularly in the northeast and including at Noen U-Loke, a site occupied at a similar time to Phum Snay. It is possible that the presence of this distinctive style indicates that the extent of the trade network, whether direct or indirect, of the people of Phum Snay reached over the Dangrek Mountains into what today is Thailand (O'Reilly et al. 2008). While some Phimai black potsherds were found in burial and nonburial contexts only one complete Phimai black bowl was found in a grave and was with Burial 9-'03. This burial was also rich in carnelian beads (over 30) and had the only complete bronze bowl excavated adjacent to her skull (O'Reilly et al. 2004). It is unfortunate that the skeleton of this adult female was so poorly preserved and little information of her health could be determined. The contact with northeast Thailand and other parts of Southeast Asia also has implications for the migration of people and the exchange of infectious disease such as leprosy and tuberculosis, which has recently been identified in a few individuals from Noen U-Loke (Tayles and Buckley 2004) and tuberculosis at Non Nok Tha (Douglas 1996). Analyses of other artifacts such as carnelian, agate, and glass beads may provide further evidence of foreign influence at Phum Snay.

This study has detailed the human skeletal data collected during two excavations at Phum Snay in Northwest Cambodia. As is evident throughout this report it has not been possible to make many definitive conclusions as the sample size was very small and the preservation and completeness of each burial was generally poor and incomplete with less than half of the burials represented by a near complete skeleton. Archaeological evidence from Phum Snay indicates that not only is this site important for reconstructing Cambodian prehistory, it also has significance in regional terms (O'Reilly et al. 2004, 2006). The limited data that could be gleaned from this skeletal sample is of considerable importance given the scarcity of prehistoric human remains so far identified and studied from within Cambodia.

\section{ACKNOWLEDGEMENTS}

This research was funded by a James Cook University Merit Research Grant 2003, Otago Research Grant 2001, the U.S. Ambassador's Fund for Cultural Preservation, and the Royal Society of New Zealand. Many thanks go to the Royal University of Fine Arts in Phnom Penh, the Ministry of Culture and Fine Arts of Cambodia, and 
the people of Phum Snay. The authors are also grateful to Dr. Nancy Tayles for comments on an earlier draft and anonymous reviewers for their constructive critiques.

\section{REFERENCES CITED}

Bentley, R. A., M. Pietrusewsky, M. T. Douglas, and T. C. Atrinson

2005 Matrilocality during prehistoric transition to agriculture in Thailand? Antiquity 79:865881.

Bentley, R. A., N. Tayles, C.F.W. Higham, C. Macpherson, and T. C. Atrinson

2007 Shifting gender relations at Khok Phanom Di, Thailand: Isotopic evidence from the skeletons. Current Anthropology 48:301-314.

Buikstra, J. E., and D. H. UbeLAKer

1994 Standards for data collection from human skeletal remains. Arkansas Archaeological Survey Research Series No. 44:206.

Chhem, R., S. K. Venkatesh, S.-C. Wang, K.-M. Wong, F. J. Ruhl, P. Y. Siew, K. Latinis, AND C. POTTIER

2004 Multislice computed tomography of two 2000-year-old skeletons in a soil matrix from Angkor, Cambodia. Canadian Association of Radiologists Journal 55 :235-241.

Dометт, K. M.

2001 Health in Late Prehistoric Thailand. British Archaeological Reports (International Series) 946. Oxford: Archaeopress.

2004 The People of Ban Lum Khao, in The Origins of the Civilization of Angkor, Vol. I, The Excavation of Ban Lum Khao: 113-151, ed. C.F.W. Higham and R. Thosarat. Bangkok: The Thai Fine Arts Department.

2005 The Skeletal Remains from Krasaing Thmei, Banteay Meachey Province, Cambodia. James Cook University, Townsville, Australia: 22.

Domett, K., AND H. R. BucKLey

2006 Cranial Trauma in Pre-Angkorian Cambodia. Homo: Journal of Comparative Biology $57: 225$.

Domett, K., and N. TAyles

2004 Tooth modification in late Iron Age in Cambodia. American Journal of Physical Anthropology Suppl. 38:88.

2006a Human biology from the Bronze Age to the Iron Age in the Mun River valley of Northeast Thailand: 220-240, in Bioarchaeology of Southeast Asia: Human Skeletal Biology of the Late Prehistoric Inhabitants of Tropical Southeast Asia and Island Southwest Pacific, ed. M. F. Oxenham and N. Tayles Cambridge: Cambridge University Press.

$2006 \mathrm{~b}$ Adult fracture patterns in prehistoric Thailand: A biocultural interpretation. International Journal of Osteoarchaeology 16:185-199.

2007 Population health from the Bronze to the Iron Age in the Mun River Valley, Northeast Thailand, in Ancient Health: Skeletal Indicators of Agricultural and Economic Intensification: 286-299, ed. M. N. Cohen and G. Crane-Kramer. Gainesville: University Press of Florida.

Douglas, M. T.

1996 Paleopathology in human skeletal remains from the pre-metal, Bronze and Iron ages, northeastern Thailand. Ph.D. diss. University of Hawai'i.

2006 Subsistence change and dental health in the people of Non Nok Tha, northeast Thailand, in Bioarchaeology of Southeast Asia: Human Skeletal Biology of the Late Prehistoric Inhabitants of Tropical Southeast Asia and Island Southwest Pacific: 191-219, ed. M. F. Oxenham and N. Tayles Cambridge: Cambridge University Press.

Halcrow, S., N. Tayles, and V. Livingstone

2008 Infant death in Late Prehistoric Southeast Asia. Asian Perspectives 47(2):371-404.

Han, K., and T. Nakahashi

1996 A comparative study of ritual tooth ablation in ancient China and Japan. Anthropological Science 104: 43-64.

Higham, C.

2002 Early Cultures of Mainland Southeast Asia. Bangkok: River Books. 
Huss-Ashmore, R., A. H. Goodman, and G. J. Armelagos

1982 Nutritional inference from paleopathology. Advances in Archaeological Method and Theory $5: 395-474$.

Larsen, C. S.

1997 Bioarchaeology: Interpreting Behavior from the Human Skeleton. Cambridge: Cambridge University Press.

Larsen, C. S., R. Shavit, and M. C. Griffin

1991 Dental caries evidence for dietary change: an archaeological context, in Advances in Dental Anthropology: 179-202, ed. M. A. Kelley and C. S. Larsen. New York: Wiley Liss.

Nelsen, K., N. Tayles, and K. Domett

2001 Missing lateral incisors in Iron Age Southeast Asians as possible indicators of dental agenesis. Archives of Oral Biology 46:963-971.

O’Reilly, D. J. W., T. Chanthourn, and K. Domett

2004 A preliminary report on the excavation of an Iron Age Cemetery at Phum Snay, Banteay Meanchey, Cambodia, 2003. Udaya Journal 5 :219-225.

O’Reilly, D. J. W., K. Domett, and S. Pheng

2008 The excavation of a Late Prehistoric Cemetery in Northwest Cambodia. Udaya 7:207222.

O’Reilly, D. J. W., and S. Pheng

2001 Recent excavations in Northwest Cambodia. Antiquity 75:265-266.

O’Reilly, D. J. W., A. von den Driesch, and V. Voeum

2006 Archaeology and archaeozoology of Phum Snay: A late prehistoric cemetery in northwestern Cambodia. Asian Perspectives $45: 188-211$.

Oxenham, M. F., K. T. Nguyen, and L. C. Nguyen

2005 Skeletal evidence for the emergence of infectious disease in Bronze and Iron Age Northern Vietnam. American Journal of Physical Anthropology 126:359-376.

Pietrusewsky, M., and M. T. Douglas

1993 Tooth ablation in old Hawai'i. Journal of the Polynesian Society 102:255-272.

2002a Ban Chiang: A Prehistoric Village Site in Northeast Thailand. I: The Human Skeletal Remains. University Museum monograph: 111. Philadelphia: Museum of Archaeology and Anthropology, University of Pennsylvania.

$2002 b$ Intensification of agriculture at Ban Chiang: Is there evidence from the skeletons? Asian Perspectives $40: 157-178$.

Pietrusewsky, M., R. Ikehara-Quebral, and M. T. Douglas

2006 The bioarchaeology of the Vat Komnou Cemetery, Angkor Borei, Cambodia. Bulletin of the Indo-Pacific Prehistory Association 26:86-97.

Sangvichien, S., P. Sirigaroon, J. B. Jorgensen, and T. Jacob

1969 Archaeological Excavations in Thailand, vol. III: Ban-Kao, part 2: The Prehistoric Thai Skeletons. Copenhagan: Munksgaard.

Sangvichien, S. J., V. Srisurin, and V. Wattanayinsakul

1985 Estimation of stature of Thai and Chinese from the length of femur, tibia and fibula. Siriraj Hospital Gazette $37: 215-218$.

Sangvichien, S. J., V. Srisurin, V. Wattanayinsakul, P. Theerarattakul, and S. RakvanichPONG

n.d. Equations for estimation of Thai's stature from the length of long bones. Department of Anatomy, Faculty of Medicine, Siriraj Hospital, Mahidol University, Bangkok.

SCRIMSHAw, N. S.

1981 Significance of the interactions of nutrition and infection in children, in Textbook of Pediatric Nutrition: 229-240, ed. R. M. Suskind. New York: Raven Press.

SJVOLD, T.

1990 Estimation of stature from long bones utilizing the line of organic correlation. Human Evolution 5 : 431-447.

Sreebny, L. M.

1983 Cereal availability and dental caries. Community Dentistry and Oral Epidemiology $11: 148-$ 155. 
Takenaka, M., K. Mine, K. Tsuchimochi, and K. Shimada

2001 Tooth removal during ritual ablation in the Jomon period. Indo-Pacific Prehistory Association Bulletin $21: 49-52$.

TAYLES, N.

1996 Tooth ablation in prehistoric Southeast Asia. International Journal of Osteoarchaeology $6: 333-345$.

1999 The Excavation of Khok Phanom Di, a Prehistoric Site in Central Thailand, Vol. 5: The People. London: Society of Antiquaries of London, Research Report no. LXI.

Tayles, N., And H. Buckley

2004 Leprosy and tuberculosis in Iron Age Southeast Asia? American Journal of Physical Anthropology $125: 239-256$.

Tayles, N., K. Domett, and K. Nelsen

2000 Agriculture and dental caries? The case of rice in prehistoric Southeast Asia. World Archaeology $32: 68-83$.

Tayles, N., S. Halcrow, and K. Domett

2007 The people of Noen U-Loke, in The Origins of the Civilization of Angkor, Vol. II: The Excavation of Noen U-Loke and Non Muang Kao: 244-304, ed. C.F.W. Higham, A. Kijngam, and S. Talbot. Bangkok: Thai Fine Arts Department.

UBELAKer, D. H.

1989 Human Skeletal Remains. Washington: Taraxacum.

WALDRON, T.

1994 Counting the Dead. The Epidemiology of Skeletal Populations. Chichester: John Wiley and Sons.

WALLWORK, C.

2006 An osteological investigation into unprovenienced remains from Koh Krabas, northwest Cambodia. Bachelor of Archaeological Practice with Combined Honours. Australian National University, Canberra.

\begin{abstract}
Excavations at a pre-Angkorian (c. 350 B.C.-A.D. 200) cemetery in the village of Phum Snay, Northwest Cambodia, have revealed 23 inhumations. This small sample of skeletal remains varies in completeness from a scatter of bone to complete articulated skeletons with an array of grave goods including bronze and iron artifacts. There is archaeological evidence for a possible militarized society, but the overall health of this small cemetery population does not provide further conclusive evidence. Demographically, the skeletal sample lacks many subadults and older adults and is skewed 2:1 toward females, but this is probably a result of poor preservation and sample size rather than any true bias in cemetery organization. Stature in both males and females is wide ranging and may indicate a heterogeneous sample either in terms of genetics or access to resources. Dental health shows evidence for sexual differentiation in diet, with females showing more caries and less advanced attrition than males, perhaps reflecting a sexual division of labor. There is also a very high proportion of adults, both male and female, with intentional ablation of the anterior dentition, most commonly involving the upper lateral incisors and upper canines. Apart from some cases of moderate joint degeneration and minor fracture (hand and clavicle), there is very little evidence for significant disease or trauma. Overall, evidence from this small sample is suggestive of a relatively healthy lifestyle but with some indicators of a non-egalitarian social structure. KeYwords: Cambodia, prehistory, pre-Angkor, skeletal remains, health, dental health.
\end{abstract}

